\title{
Perbandingan Penduga M, S, dan MM pada Regresi Linier dalam Menangani Keberadaan Outlier
}

\author{
Hanifah Lainun', Georgina M Tinungki ${ }^{2}, \operatorname{Amran}^{3}$
}

\begin{abstract}
Abstrak
Metode Kuadrat Terkecil (MKT) merupakan metode penduga parameter yang paling banyak digunakan pada analisis regresi. MKT merupakan metode penduga parameter tak bias yang baik selama asumsi komponen galatnya terpenuhi. Namun dalam aplikasinya sering ditemui terjadinya pelanggaran asumsi. Diantaranya, pelanggaran asumsi galat berdistribusi normal disebabkan adanya outlier pada data amatan. Oleh karena itu, dibutuhkan suatu metode yang kekar terhadap keberadaan outlier. Metode pendugaan parameter yang kekar terhadap keberadaan outlier pada regresi linier diantaranya ialah penduga $\mathrm{M}$, penduga $\mathrm{S}$, dan penduga MM yang masing-masing memiliki keunggulan dari segi efisiensi dan breakdown point yang tinggi. Tujuan dari penelitian ini adalah untuk membandingkan penduga $\mathrm{M}, \mathrm{S}$, dan MM dalam menduga parameter regresi pada analisis regresi linier sederhana terhadap keberadaan outlier menggunakan data simulasi. Simulasi dilakukan untuk ukuran sampel yang berbeda (20,60, dan 120) ketika terdapat $20 \%$ dan $45 \%$ outlier pada variabel bebas dan variabel terikat. Metode terbaik ialah metode dengan Standard Error (SE) dan Mean Square Error (MSE) terkecil. Hasil yang diperoleh menunjukkan bahwa penduga MM lebih baik dibandingkan penduga $\mathrm{M}$ dan penduga $\mathrm{S}$.
\end{abstract}

Kata Kunci: Regresi Robust, Penduga M, Penduga S, Penduga MM, Outlier

\section{Pendahuluan}

Analisis regresi merupakan suatu metode statistika yang digunakan untuk mengkaji hubungan antara variabel terikat dan satu atau lebih variabel bebas. Metode yang banyak digunakan untuk mengestimasi parameter model regresi ialah Metode Kuadrat Terkecil (MKT) yang meminimumkan jumlah kuadrat galat. Disamping kemudahan dalam komputasinya, MKT merupakan penduga tak bias yang baik selama asumsi komponen galat $\left(e_{i}\right)$ dalam model yang diberikan terpenuhi. Namun dalam aplikasinya seringkali ditemui terjadi pelanggaran asumsi. Diantaranya ialah terlanggarnya asumsi galat berdistribusi $N \sim\left(0, \sigma^{2}\right)$ yang disebabkan adanya outlier pada data amatan sehingga diperlukan suatu metode yang kekar terhadap keberadaan outlier.

Regresi robust adalah metode regresi yang digunakan ketika data pengamatan mengandung outlier yang mempengaruhi model. Metode ini penting untuk menganalisis data yang mengandung outlier agar model yang dihasilkan kekar terhadap keberadaan outlier [6]. Kekekaran suatu penduga dapat diukur dari breakdown point dan efesiensi penduga. Metode penduga parameter yang robust terhadap keberadaan outlier pada regresi linier diantaranya ialah penduga $\mathrm{M}$ yang mana efisiensinya dapat mencapai hingga 95\%, penduga S dengan breakdown point yang dapat mencapai hingga 50\%, dan penduga MM yang merupakan kombinasi dari efisiensi dan breakdown point yang tinggi.

Penelitian yang mengkaji mengenai penggunaan regresi robust pada data yang mengandung outlier ialah Gad dan Qura [9] dan Cankaya dan Abaer [5] yang membandingkan beberapa metode robust dan MKT apabila terdapat outlier pada variabel terikat $(y)$. Penelitian ini akan membandingkan

hanifahlainun311@gmail.com ${ }^{1}$,ina_matematika@yahoo.co.id ${ }^{2}$,amranihsani@gmail.com ${ }^{3}$

${ }^{1,2,3}$ Program Studi Statistika, Departemen Matematika, FMIPA, Universitas Hasanuddin 


\section{Hanifah Lainun, Georgina M Tinungki, Amran}

penduga $\mathrm{M}$, penduga S, dan penduga MM ketika data amatan mengandung $20 \%$ dan $45 \%$ outlier pada variabel terikat, outlier pada variabel bebas (good leverage point), dan outlier pada variabel bebas dan variabel terikat (bad leverage point) untuk tiga ukuran sampel berbeda pada regresi linier sederhana.

\section{Tinjuan Pustaka}

\subsection{Analisis Regresi}

Model regresi linier secara umum dapat dinyatakan sebagai

dengan,

$$
y_{i}=\beta_{0}+\beta_{1} x_{i 1}+\beta_{2} x_{i 2}+\cdots+\beta_{p} x_{i p}+e_{i}, \quad(i=1,2, \ldots, n)
$$

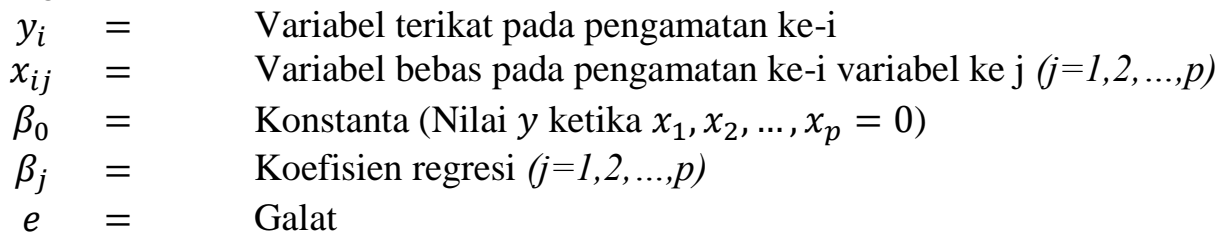

Persamaan (1) dapat dituliskan kedalam notasi matriks sebagaimana pada persamaan (2).

$$
y=X \beta+e
$$

Metode Kuadrat Terkecil (MKT) adalah suatu metode penaksiran parameter pada analisis regresi linier yang paling banyak digunakan dengan tujuan untuk meminimumkan jumlah kuadrat galat.

$$
\min \sum_{i=1}^{n} e_{i}{ }^{2}
$$

Persamaan normal untuk memperoleh nilai penduga $\beta$ menggunakan metode kuadrat terkecil adalah dengan memperoleh turunan parsial dari persamaan (3) terhadap $\beta$ dan menyamakannya dengan nol.

\subsection{Outlier}

$$
\begin{gathered}
\frac{\partial}{\partial \boldsymbol{\beta}}\left[\boldsymbol{e}^{\prime} \boldsymbol{e}\right]=\frac{\partial}{\partial \boldsymbol{\beta}}\left[(\boldsymbol{y}-\boldsymbol{X} \boldsymbol{\beta})^{\prime}(\boldsymbol{y}-\boldsymbol{X} \boldsymbol{\beta})\right]=0 \\
\left.\frac{\partial}{\partial \boldsymbol{\beta}}\right|_{\boldsymbol{\beta}=\widehat{\boldsymbol{\beta}}}\left[\boldsymbol{y}^{\prime} \boldsymbol{y}-2\left(\boldsymbol{X}^{\prime} \boldsymbol{y}\right) \boldsymbol{\beta}+\left(\boldsymbol{X}^{\prime} \boldsymbol{X}\right) \boldsymbol{\beta}^{2}\right]=0 \\
-2 \boldsymbol{X}^{\prime} \boldsymbol{y}+2\left(\boldsymbol{X}^{\prime} \boldsymbol{X}\right) \widehat{\boldsymbol{\beta}}=0 \\
\left(\boldsymbol{X}^{\prime} \boldsymbol{X}\right) \widehat{\boldsymbol{\beta}}=\boldsymbol{X}^{\prime} \boldsymbol{y} \\
\left(\boldsymbol{X}^{\prime} \boldsymbol{X}\right)^{-1}\left(\boldsymbol{X}^{\prime} \boldsymbol{X}\right) \widehat{\boldsymbol{\beta}}=\left(\boldsymbol{X}^{\prime} \boldsymbol{X}\right)^{-1} \boldsymbol{X}^{\prime} \boldsymbol{y} \\
\widehat{\boldsymbol{\beta}}=\left(\boldsymbol{X}^{\prime} \boldsymbol{X}\right)^{-1} \boldsymbol{X}^{\prime} \boldsymbol{y}
\end{gathered}
$$

Salah satu langkah awal untuk mendapatkan analisis yang tepat ialah mendeteksi keberadaan outlier. Johnson (1992) mendefinisikan outlier sebagai pengamatan dalam kumpulan data yang tampaknya tidak konsisten dengan data lainnya. Penghapusan outlier dari kumpulan data yang dianalisis dapat secara dramatis mempengaruhi kinerja model regresi [3]. Outlier harus dihilangkan jika ada alasan yang tepat. Alternatif lainnya ialah menggunakan regresi robust, yang mana algoritmanya memberi bobot lebih sedikit pada outlier namun tidak membuangnya [2]. Chen [6] menyebutkan bahwa secara historis, tiga jenis permasalahan outlier yang ditangani dengan regresi robust: 1) Outlier di variabel terikat $(y), 2)$ Outlier di variabel bebas $(x)$ yang juga disebut dengan leverage point dan 3) Outlier di variabel terikat $(y)$ dan variabel bebas $(x)$.

Ada banyak kesulitan dalam proses identifikasi outlier. Bengal [3] menyebutkan bahwa data yang mengandung beberapa outlier atau outlier yang bergerombol rentan terhadap efek tumpang tindih (masking and swamping effect). Uji statistik yang dapat digunakan untuk mengidentifikasi keberadaan multiple outlier ialah uji Hampel [8]. Uji ini menggunakan median dan MAD yang mana lebih kekar terhadap keberadaan outlier dibandingkan rata-rata dan standar deviasi. Pada uji hampel, pengamatan $x_{i}$ teridentifikasi sebagai outlier apabila

$$
x_{i}-\operatorname{median}\left(x_{i}\right)>4.5 \operatorname{MAD}\left(x_{i}\right)
$$




\subsection{Metode Robust}

Metode Kuadrat Terkecil dengan $n$ observasi, untuk model $\boldsymbol{y}=\boldsymbol{X} \boldsymbol{\beta}+\boldsymbol{e}$ dengan $p$ parameter mengharuskan terpenuhinya beberapa asumsi agar hasil yang diperoleh dapat mewakili populasi yang sebenarnya. Dalam aplikasinya, seringkali ditemui terjadi pelanggaran asumsi tersebut. Diantaranya ialah terlanggarnya asumsi galat berdistribusi $N \sim\left(0, \sigma^{2}\right)$ yang disebabkan adanya outlier pada data amatan. Regresi robust adalah metode regresi yang digunakan ketika terdapat beberapa outlier yang mempengaruhi model. Agar dapat mencapai hal ini regresi robust membatasi pengaruh dari outlier [6]. Selain itu, diwaktu yang bersamaan metode ini dapat digunakan untuk mengidentifikasi data mana yang merupakan outlier.

Andersen [1] menyebutkan dua kriteria kekekaran suatu penduga yang patut diperhitungkan yaitu breakdown point dan efesiensi penduga. Breakdown point adalah proporsi atau persentase data yang terkontaminasi yang masih dapat ditangani suatu penduga sebelum menghasilkan dugaan yang keliru. Sementara itu, suatu penduga dapat dikatakan efisien jika penduga tersebut yang paling akurat dibandingkan penduga tak bias lainnya.

\subsubsection{Penduga $\mathrm{M}$}

Penduga M dalam konteks regresi pertama kali diperkenalkan oleh Huber (1973) sebagai hasil pendekatan dari penduga kuadrat terkecil yang robust. Meskipun penduga M tidak dapat menaksir parameter dengan baik apabila terdapat leverage point, penduga $\mathrm{M}$ populer ketika dalam aplikasinya leverage point bukanlah suatu masalah [10]. Penduga M meminimumkan fungsi objektif dari galat:

$$
\widehat{\boldsymbol{\beta}}_{m}=\min \sum_{i=1}^{n} \rho\left(\frac{y_{i}-\boldsymbol{x}_{i}{ }^{\prime} \boldsymbol{\beta}}{\sigma}\right)
$$

Langkah-langkah yang dilakukan dalam mengestimasi parameter dengan penduga $\mathrm{M}$ adalah:

1. Menaksir $\boldsymbol{\beta}$ awal yaitu $\widehat{\boldsymbol{\beta}}_{(0)}$ dengan menggunakan metode kuadrat terkecil.

2. Menghitung nilai residual $e_{i}=y_{i}-\hat{y}_{i}$.

3. Menghitung nilai

4. Menghitung nilai $u_{i}=e_{i} / \hat{\sigma}_{i}$

$$
\hat{\sigma}_{i}=\frac{\text { median }\left|e_{i}-\operatorname{median}\left(e_{i}\right)\right|}{0.6745}
$$

5. Menghitung nilai boboti $\left(W_{i}\right)$ menggunakan fungsi pembobot Tukey's bisquare dengan nilai tuning constant $c=4.685$ sehingga diperoleh efisiensi sebesar $95 \%$.

$$
W(u, c)=\left\{\begin{array}{cl}
\left(1-\frac{u^{2}}{4.685^{2}}\right)^{2}, & \text { jika }|u|<4.685 \\
0, & \text { lainnya }
\end{array}\right.
$$

6. Menghitung $\widehat{\boldsymbol{\beta}}_{M}$ menggunakan kuadrat terkecil terboboti berdasarkan nilai bobot $W_{i}$.

$$
\widehat{\boldsymbol{\beta}}_{M}=\left(\boldsymbol{X}^{\prime} \boldsymbol{W} \boldsymbol{X}\right)^{-1} \boldsymbol{X}^{\prime} \boldsymbol{W} \boldsymbol{y}
$$

7. Mengulangi langkah 2-6 sampai diperoleh nilai $\widehat{\boldsymbol{\beta}}_{M}$ yang konvergen.

\subsubsection{Penduga $\mathrm{S}$}

Penduga S pertama kali diperkenalkan oleh Rousseeuw dan Yohai (1984) dengan breakdown point yang dapat mencapai hingga 50\%. Dengan cara yang sama metode kuadrat terkecil meminimumkan ragam dari galat, penduga $S$ meminimumkan dispersi dari galat,

$$
\widehat{\boldsymbol{\beta}}_{s}=\min \sigma(\boldsymbol{\beta})
$$


dimana dispersi $\sigma(\beta)$ adalah solusi dari

$$
\frac{1}{n} \sum_{i=1}^{n} \rho\left(\frac{y_{i}-\boldsymbol{x}_{i}^{\prime} \boldsymbol{\beta}}{\sigma}\right)=K
$$

dengan $\mathrm{K}$ adalah nilai konstan yang tepat untuk memastikan kekonsistenan.

Langkah-langkah yang dilakukan dalam mengestimasi parameter dengan penduga $S$ adalah:

1. Menaksir $\boldsymbol{\beta}$ awal yaitu $\widehat{\boldsymbol{\beta}}_{(0)}$ dengan menggunakan metode kuadrat terkecil.

2. Menghitung nilai residual $e_{i}=y_{i}-\hat{y}_{i}$.

3. Menghitung nilai

$$
\hat{\sigma}_{s}=\left\{\begin{array}{cl}
\frac{\text { median }\left|e_{i}-\operatorname{median}\left(e_{i}\right)\right|}{0.6745}, & \text { iterasi pertama } \\
\sqrt{\frac{1}{n K} \sum_{i=1}^{n} w_{i} e_{i}^{2}}, \text { lainnya }
\end{array}\right.
$$

4. Menghitung nilai $u_{i}=e_{i} / \hat{\sigma}_{i}$

5. Menghitung nilai boboti $\left(W_{i}\right)$ menggunakan fungsi pembobot Tukey's bisquare dengan nilai tuning constant $c=1.547$ sehingga diperoleh breakdown point sebesar $50 \%$.

$$
W(u, c)=\left\{\begin{array}{cl}
\left(1-\frac{u^{2}}{1.547^{2}}\right)^{2}, & \text { jika }|u|<1.547 \\
0, & \text { lainnya }
\end{array}\right.
$$

6. Menghitung $\hat{\beta}_{S}$ menggunakan kuadrat terkecil terboboti berdasarkan nilai bobot $W_{i}$.

$$
\widehat{\boldsymbol{\beta}}_{s}=\left(\boldsymbol{X}^{\prime} \boldsymbol{W} \boldsymbol{X}\right)^{-1} \boldsymbol{X}^{\prime} \boldsymbol{W} \boldsymbol{y}
$$

7. Mengulangi langkah 2-6 sampai diperoleh nilai $\widehat{\boldsymbol{\beta}}_{s}$ yang konvergen.

\subsubsection{Penduga MM}

Penduga MM adalah prosedur untuk menaksir parameter regresi menggunakan penduga $\mathrm{S}$ yang meminimumkan scale dari galat pada penduga $\mathrm{M}$ dengan breakdown point hingga 50\%, kemudian melanjutkan proses dengan penduga $M$ yang efisien. Penduga MM adalah solusi dari

$$
\widehat{\boldsymbol{\beta}}_{m m}=\min \sum_{i=1}^{n} \rho\left(\frac{y_{i}-\boldsymbol{X}_{i}{ }^{\prime} \boldsymbol{\beta}}{\sigma}\right)
$$

Langkah-langkah yang dilakukan dalam mengestimasi parameter dengan penduga MM adalah:

1. Menaksir $\boldsymbol{\beta}$ awal yaitu $\widehat{\boldsymbol{\beta}}_{(0)}$ dengan menggunakan penduga $\mathrm{S}$ sehingga diperoleh breakdown point sebesar $50 \%$.

2. Menghitung nilai residual $e_{i}=y_{i}-\hat{y}_{i}$.

3. Menghitung nilai

4. Menghitung nilai $u_{i}=e_{i} / \hat{\sigma}_{i}$

$$
\hat{\sigma}_{i}=\frac{\text { median } \mid e_{i}-\text { median }\left(e_{i}\right) \mid}{0.6745}
$$

5. Menghitung nilai boboti $\left(W_{i}\right)$ menggunakan fungsi pembobot Tukey's bisquare dengan nilai tuning constant $c=4.685$ sehingga diperoleh efisiensi sebesar $95 \%$.

$$
W(u, c)=\left\{\begin{array}{cl}
\left(1-\frac{u^{2}}{4.685^{2}}\right)^{2}, & \text { jika }|u|<4.685 \\
0, & \text { lainnya }
\end{array}\right.
$$

6. Menghitung $\widehat{\boldsymbol{\beta}}_{M M}$ menggunakan kuadrat terkecil terboboti berdasarkan nilai bobot $W_{i}$.

$$
\widehat{\boldsymbol{\beta}}_{M M}=\left(\boldsymbol{X}^{\prime} \boldsymbol{W} \boldsymbol{X}\right)^{-1} \boldsymbol{X}^{\prime} \boldsymbol{W} \boldsymbol{y}
$$


7. Mengulangi langkah 2-6 sampai diperoleh nilai $\widehat{\boldsymbol{\beta}}_{M M}$ yang konvergen.

\section{Data Simulasi}

Prosedur simulasi yang dilakukan adalah menggunakan Model Based Simulation dengan algoritma sebagai berikut.

1. Menentukan parameter bagi populasi yaitu $\beta_{0}=\beta_{1}=4$.

2. Membangkitkan $e_{i}, X_{i}$, dan $y_{i}$ untuk $i=1,2, \ldots, N$ menggunakan softwere SAS 9.2 dengan ketentuan sebagaimana pada Tabel 3.1.

Tabel 3. 1 Kriteria Data Simulasi

\begin{tabular}{ccccc}
\hline & Data 'normal' & Outlier di y & Outlier di x & Outlier di x dan y \\
\hline $\mathrm{N}$ & 1250 & 250 & 250 & 250 \\
$e_{i}$ & $N(0,1)$ & $N(0,1)$ & $N(0,1)$ & $N(0,1)$ \\
$x_{i}$ & $N(5,2)$ & $N(5,2)$ & $N(100,20)$ & $N(100,20)$ \\
$y_{i}$ & $\beta_{0}+\beta_{1} X_{i}+e_{i}$ & $200+e_{i}$ & $\beta_{0}+\beta_{1} X_{i}+e_{i}$ & $200+e_{i}$
\end{tabular}

3. Mengambil sampel secara acak untuk $n=20, n=60$, dan $n=120$. Adapun persentase data 'normal' dan data outlier (baik pada variabel bebas $(x)$, variabel terikat $(y)$, dan variabel bebas $(x)$ dan variabel terikat $(y)$ ) ditetapkan: 1) $80 \%$ dan 20\% dari banyaknya sampel dan 2) 55\% dan $45 \%$ dari banyaknya sampel.

4. Melakukan penaksiran parameter menggunakan metode kuadrat terkecil (MKT), penduga M, penduga $S$, dan penduga MM.

5. Menghitung Mean Square Error (MSE) berdasarkan model regresi yang diperoleh pada MKT, penduga $\mathrm{M}$, penduga $\mathrm{S}$ dan penduga $\mathrm{MM}$.

$$
M S E=(\widehat{\boldsymbol{\beta}}-\boldsymbol{\beta})^{\prime}(\widehat{\boldsymbol{\beta}}-\boldsymbol{\beta})
$$

dengan $\widehat{\boldsymbol{\beta}}$ adalah vektor parameter dugaan dan $\boldsymbol{\beta}$ merupakan vektor koefisien model yang sebenarnya.

6. Mengulangi langkah 3-5 sebanyak lima kali.

7. Menentukan metode yang paling baik yaitu metode dengan MSE terkecil.

\section{Hasil dan Pembahasan}

Sebelum melakukan penaksiran parameter, identifikasi outlier dilakukan pada data simulasi untuk tiga jumlah sampel dan tiga jenis outlier yang berbeda untuk memastikan bahwa data yang diperoleh telah sesuai dengan tujuan penelitian. Statistik uji yang digunakan untuk melihat pengamatan keberapa yang teridentifikasi sebagai outlier ialah uji hampel pada Persamaan (4). Hasil yang diperoleh menunjukkan bahwa $20 \%$ dan $45 \%$ data terakhir dari sampel teridentifiaksi sebagai outlier.

Pada berbagai ukuran sampel dan jenis outlier yang berbeda diperoleh nilai Mean Square Error (MSE) ketika menggunakan MKT, penduga M, penduga S, dan penduga MM. Berdasarkan hasil yang diperoleh dapat diambil kesimpulan sebagai berikut.

Skenario 1: $20 \%$ outlier di variabel terikat $y$

Hasil dugaan parameter MKT adalah yang terburuk berdasarkan MSE yang diperoleh. Selain itu, MKT juga memiliki Standard Error (SE) yang terbesar terutama pada sampel kecil yaitu $n=20$ dibanding metode lainnya. Hal ini disebabkan model yang diperoleh dari MKT bias terhadap 
keberadaan outlier menyebabkan interval kepercayaan lebih lebar. Secara keseluruhan, SE semakin kecil seiring bertambah besarnya ukuran sampel. Sementara itu, metode robust tetap tidak dipengaruhi oleh keberadaan outlier dengan memberikan bobot yang kecil pada data yang diidentifikasi sebagai outlier. Diantara ketiga metode robust, penduga MM memiliki MSE yang paling minimum yang kemudian disusul oleh penguga $M$, dan terakhir penduga $S$.

Skenario 2: $45 \%$ outlier di variabel terikat $y$

Diperoleh bahwa penduga M menghasilkan dugaan yang keliru sebagaimana MKT pada berbagai ukuran sampel. Hal ini disebabkan pada penduga $M$, semakin tinggi efisiensinya maka kemampuan dalam mendeteksi outlier akan berkurang. Pada penelitian ditetapkan nilai $\mathrm{c}=4.685$ yang menghasilkan efisiensi sebesar 95\%. Oleh karena itu, disarankan untuk menggunakan nilai tuning constat $c$ yang lebih kecil apabila proporsi dari outlier besar dan mendekati $50 \%$ sehingga kemampuan penduga $\mathrm{M}$ dalam mendeteksi outlier lebih baik meski efisiensinya berkurang. Sementara itu, penduga $\mathrm{S}$ dan penduga MM tetap dapat mengestimasi parameter $\beta$ dengan baik dengan penduga MM menghasilkan MSE yang lebih kecil dibandingkan penduga S.

Skenario 3: $20 \%$ outlier di variabel bebas $x$

MKT merupakan metode terbaik dengan MSE paling minimum yang kemudian disusul oleh penduga MM, peduga $\mathrm{M}$, dan terakhir penduga $\mathrm{S}$.

Skenario 4: $45 \%$ outlier di variabel bebas $x$

Hasil yang diperoleh sama halnya ketika tedapat $20 \%$ outlier pada variabel bebas. MKT merupakan metode terbaik dengan MSE paling minimum yang kemudian disusul oleh penduga MM, peduga $\mathrm{M}$, dan terakhir penduga $\mathrm{S}$.

Skenario 5: $20 \%$ outlier di variabel terikat $y$ dan variabel bebas $x$

Diperoleh bahwa penduga $M$ menghasilkan dugaan yang keliru sebagaimana MKT pada berbagai ukuran sampel. Dugaan parameter yang diperoleh bias terhadap keberadaan outlier menyebabkan nilai MSE yang besar. Hal ini disebabkan karena bad leverage point memberi pengaruh yang besar terhadap dugaan kemiringan garis regresi apabila metode dengan breakdown point yang rendah digunakan. Sementara itu, penduga $S$ dan penduga MM tetap dapat mengestimasi parameter regresi dengan baik dengan penduga MM memiliki MSE yang lebih kecil dibandingkan penduga $S$.

Skenario 6: $45 \%$ outlier di variabel terikat $y$ dan variabel bebas $x$

Kinerja dari keempat metode menurun untuk $n=20$ dimana MSE yang dihasilkan lebih besar dibadingkan MSE yang diperoleh pada kondisi outlier lainnya. Sementara itu, untuk $n=60$ dan $n=60$ hasil yang diperoleh sama halnya ketika terdapat outlier di variabel terikat dan variabel bebas sebanyak $20 \%$. MKT dan penduga M menghasilkan dugaan parameter yang keliru sehingga diperoleh nilai MSE yang besar, sementara penduga S dan penduga MM tetap dapat mengestimasi parameter regresi dengan baik dengan penduga MM memiliki MSE yang lebih kecil dibandingkan penduga $S$.

\section{Kesimpulan}

Pada penelitian ini berdasarkan MSE yang diperoleh, penduga MM lebih baik dibandingkan penduga $\mathrm{M}$ dan penduga $\mathrm{S}$ ketika terdapat outlier pada variabel terikat dan outlier ada variabel terikat dan variabel bebas. Namun, kelemahan dari penduga MM ialah ketika ukuran sampel kecil dan proporsi outlier besar yaitu mendekati nilai breakdown point. Adapun ketika terdapat outlier pada 
variabel bebas, MKT tetap dapat menaksir parameter regresi dengan baik, bahkan dapat meningkatkan keakuratan koefisien regresi.

\section{Daftar Pustaka}

[1] Andersen, R., 2008. Modern Method for Robust Regression. London: Sage Publication.

[2] Anonymous. tahun. Outliers. (http://web.sonoma.edu/users/c/cuellar/econ317/Outliers.pdf diakses pada taggal 27 September 2017)

[3] Ben-Gal, Irad. 2005. Outlier detection. Data mining and knowledge discovery handbook, 131-146.

[4] Blatná, Dagmar. 2006. Outliers in regression. Trutnov, 30, 2006-03.

[5] Cankaya, Soner dan Samet Hasan Abaci. 2015. Comparative Study of Some Estimation Methods in Simple Linier Regression Model for Different Sample Sizes in Presence of Outliers. Turkish Journal of Agliculture - Food Science and Thechnology, 3(6): 380386.

[6] Chen, Colin. 2002. Paper 256-27 Robust Regression and Outlier Detection with the ROBUSTREG Procedure. In Proceedings of the Proceedings of the Twenty-Seventh Annual SAS Users Group International Conference.

[7] Draper, N. R. dan K. Smith (1998). Applied Regression Analysis. Third edition. New York: Wiley.

[8] Farazi, Manzur Rahman. 2015. Identification of Outlier in Gene Expression Data [Thesis]. Indiana: Ball State University.

[9] Gad, Ahmed M. dan Maha E. Qura. 2016. Regression Estimation in Presence of Outliers: A Comparative Study. International Journal of Probability and Statistics 2016, 5(3): 65-72.

[10] SAS Institute Inc, 2009. SAS/STAT ${ }^{\circledR}$ 9.2, User's Guide, Chapter 74: The ROBUSTREG Procedure, Second Edition, Cary, NC: USA

[11] Stuart, Chaterine. 2011. Robust regression. Department of Mathematical Sciences, Durham University, 169. 
Hanifah Lainun, Georgina M Tinungki, Amran

Lampiran: Rata-rata MSE pada berbagai kondisi

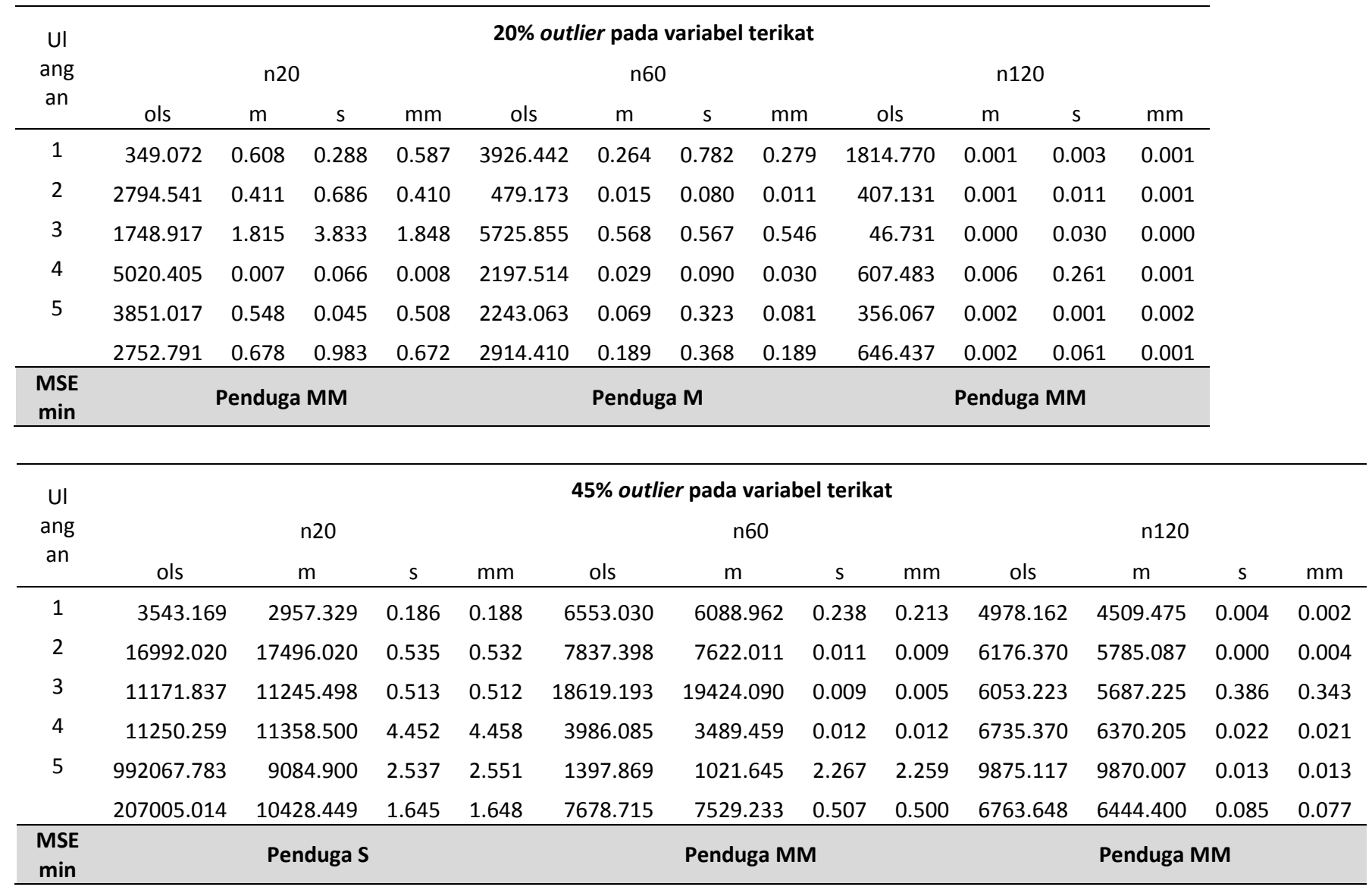

\begin{tabular}{|c|c|c|c|c|c|c|c|c|c|c|c|c|}
\hline \multirow{3}{*}{$\begin{array}{c}\text { Ulang } \\
\text { an }\end{array}$} & \multicolumn{12}{|c|}{$20 \%$ outlier pada variabel bebas } \\
\hline & \multicolumn{4}{|c|}{$\mathrm{n} 20$} & \multicolumn{4}{|c|}{ n60 } & \multicolumn{4}{|c|}{ n120 } \\
\hline & ols & $\mathrm{m}$ & s & $\mathrm{mm}$ & ols & $\mathrm{m}$ & s & $\mathrm{mm}$ & ols & $\mathrm{m}$ & s & $\mathrm{mm}$ \\
\hline 1 & 0.000 & 0.002 & 0.034 & 0.005 & 0.003 & 0.002 & 0.048 & 0.000 & 0.003 & 0.005 & 0.000 & 0.008 \\
\hline 2 & 0.168 & 0.452 & 0.603 & 0.494 & 0.127 & 0.124 & 0.300 & 0.122 & 0.021 & 0.016 & 0.002 & 0.012 \\
\hline 3 & 0.106 & 0.385 & 0.884 & 0.208 & 0.003 & 0.006 & 0.226 & 0.015 & 0.006 & 0.006 & 0.004 & 0.005 \\
\hline 4 & 0.269 & 0.378 & 0.679 & 0.456 & 0.017 & 0.012 & 0.051 & 0.006 & 0.001 & 0.000 & 0.105 & 0.001 \\
\hline 5 & 0.009 & 0.013 & 0.081 & 0.020 & 0.002 & 0.002 & 0.002 & 0.002 & 0.000 & 0.000 & 0.031 & 0.000 \\
\hline MSE min & \multicolumn{4}{|c|}{ OLS } & \multicolumn{4}{|c|}{ Penduga $\mathrm{M}$} & \multicolumn{4}{|c|}{ Penduga MM } \\
\hline
\end{tabular}

\begin{tabular}{|c|c|c|c|c|c|c|c|c|c|c|c|c|}
\hline \multirow{3}{*}{$\begin{array}{c}\text { Ulang } \\
\text { an }\end{array}$} & \multicolumn{12}{|c|}{$45 \%$ outlier pada variabel bebas } \\
\hline & \multicolumn{4}{|c|}{ n20 } & \multicolumn{4}{|c|}{ n60 } & \multicolumn{4}{|c|}{ n120 } \\
\hline & ols & $\mathrm{m}$ & s & $\mathrm{mm}$ & ols & $\mathrm{m}$ & s & $\mathrm{mm}$ & ols & $\mathrm{m}$ & s & $\mathrm{mm}$ \\
\hline 1 & 0.040 & 0.080 & 0.083 & 0.118 & 0.008 & 0.014 & 0.100 & 0.022 & 0.002 & 0.002 & 0.012 & 0.003 \\
\hline 2 & 0.018 & 0.027 & 0.240 & 0.047 & 0.022 & 0.033 & 0.232 & 0.042 & 0.012 & 0.032 & 0.476 & 0.072 \\
\hline 3 & 0.025 & 0.015 & 0.257 & 0.016 & 0.029 & 0.022 & 0.015 & 0.016 & 0.001 & 0.001 & 0.080 & 0.005 \\
\hline 4 & 0.266 & 0.254 & 0.000 & 0.168 & 0.156 & 0.151 & 0.400 & 0.147 & 0.013 & 0.006 & 0.067 & 0.003 \\
\hline
\end{tabular}


Hanifah Lainun, Georgina M Tinungki, Amran

\begin{tabular}{|c|c|c|c|c|c|c|c|c|c|c|c|c|}
\hline \multirow[t]{2}{*}{5} & 0.070 & 0.188 & 0.655 & 0.295 & 0.005 & 0.009 & 0.041 & 0.012 & 0.007 & 0.008 & 0.138 & 0.010 \\
\hline & 0.084 & 0.113 & 0.247 & 0.129 & 0.044 & 0.046 & 0.158 & 0.048 & 0.007 & 0.010 & 0.155 & 0.019 \\
\hline MSE min & \multicolumn{4}{|c|}{ OLS } & \multicolumn{4}{|c|}{ OLS } & \multicolumn{4}{|c|}{ OLS } \\
\hline
\end{tabular}

\begin{tabular}{|c|c|c|c|c|c|c|c|c|c|c|c|c|}
\hline \multirow{3}{*}{$\begin{array}{c}\text { Ul } \\
\text { ang } \\
\text { an }\end{array}$} & \multicolumn{12}{|c|}{$20 \%$ outlier pada variabel terikat dan variabel bebas } \\
\hline & \multicolumn{4}{|c|}{ n20 } & \multicolumn{4}{|c|}{ n60 } & \multicolumn{4}{|c|}{ n120 } \\
\hline & ols & $\mathrm{m}$ & s & $\mathrm{mm}$ & ols & $\mathrm{m}$ & s & $\mathrm{mm}$ & ols & $\mathrm{m}$ & s & $\mathrm{mm}$ \\
\hline 1 & 159.475 & 121.265 & 0.288 & 0.587 & 135.952 & 102.662 & 0.782 & 0.279 & 170.330 & 135.282 & 0.003 & 0.001 \\
\hline 2 & 90.433 & 92.182 & 0.686 & 0.410 & 178.942 & 155.108 & 0.080 & 0.011 & 172.846 & 132.627 & 0.011 & 0.001 \\
\hline 3 & 150.780 & 124.925 & 3.833 & 1.848 & 182.404 & 137.586 & 0.567 & 0.546 & 173.728 & 124.671 & 0.030 & 0.000 \\
\hline 4 & 283.296 & 191.565 & 0.066 & 0.008 & 210.583 & 189.847 & 0.090 & 0.030 & 183.717 & 120.706 & 0.261 & 0.001 \\
\hline \multirow[t]{2}{*}{5} & 204.802 & 171.381 & 0.045 & 0.508 & 172.269 & 150.550 & 0.323 & 0.081 & 159.828 & 107.239 & 0.001 & 0.003 \\
\hline & 177.757 & 140.263 & 0.983 & 0.672 & 176.030 & 147.151 & 0.368 & 0.189 & 172.090 & 124.105 & 0.061 & 0.001 \\
\hline $\begin{array}{c}\text { MSE } \\
\text { min }\end{array}$ & \multicolumn{4}{|c|}{ Penduga MM } & \multicolumn{4}{|c|}{ Penduga MM } & \multicolumn{4}{|c|}{ Penduga MM } \\
\hline
\end{tabular}

\begin{tabular}{|c|c|c|c|c|c|c|c|c|c|c|c|c|}
\hline \multirow{3}{*}{$\begin{array}{c}\text { UI } \\
\text { ang } \\
\text { an }\end{array}$} & \multicolumn{12}{|c|}{$45 \%$ outlier pada variabel terikat dan variabel bebas } \\
\hline & \multicolumn{4}{|c|}{$\mathrm{n} 20$} & \multicolumn{4}{|c|}{ n60 } & \multicolumn{4}{|c|}{ n120 } \\
\hline & ols & $\mathrm{m}$ & $\mathrm{s}$ & $\mathrm{mm}$ & ols & $\mathrm{m}$ & s & $\mathrm{mm}$ & ols & $\mathrm{m}$ & s & $\mathrm{mm}$ \\
\hline 1 & 287.449 & 166.349 & 49.108 & 56.195 & 321.302 & 157.773 & 0.238 & 0.213 & 247.508 & 137.187 & 0.004 & 0.002 \\
\hline 2 & 203.387 & 101.055 & 77.236 & 95.444 & 349.387 & 133.489 & 0.011 & 0.009 & 289.996 & 160.894 & 0.000 & 0.004 \\
\hline 3 & 292.252 & 159.141 & 34.865 & 35.681 & 221.549 & 135.718 & 0.009 & 0.005 & 324.248 & 103.477 & 0.386 & 0.343 \\
\hline 4 & 175.073 & 127.158 & 69.325 & 70.127 & 402.687 & 176.612 & 0.012 & 0.011 & 232.601 & 123.298 & 0.022 & 0.021 \\
\hline \multirow[t]{2}{*}{5} & 243.136 & 124.362 & 125.467 & 124.833 & 338.189 & 88.891 & 15.457 & 15.417 & 349.972 & 154.534 & 0.013 & 0.013 \\
\hline & 240.259 & 135.613 & 71.200 & 76.456 & 326.623 & 138.496 & 3.145 & 3.131 & 288.865 & 135.878 & 0.085 & 0.077 \\
\hline $\begin{array}{c}\text { MSE } \\
\text { min }\end{array}$ & \multicolumn{4}{|c|}{ Penduga S } & \multicolumn{4}{|c|}{ Penduga MM } & \multicolumn{4}{|c|}{ Penduga MM } \\
\hline
\end{tabular}

